\title{
Infratemporal fossa synovial sarcoma in a 3-month-old infant: an extremely rare tumour in infancy
}

Mięsak maziówkowy umiejscowiony w dole podskroniowym u 3-miesięcznego niemowlęcia: niezwykle rzadki guz w okresie niemowlęcym

\author{
1 Department of Otorhinolaryngology - Head and Neck Surgery, School of Medical Sciences, Universiti Sains Malaysia Health Campus, Kota Bharu, Kelantan, Malaysia \\ ${ }^{2}$ Department of Otorhinolaryngology - Head and Neck Surgery, Hospital Sultan Ismail, Johor Bahru, Malaysia \\ Correspondence: Sakinah Mohamad, Department of Otorhinolaryngology - Head and Neck Surgery, School of Medical Sciences, Universiti Sains Malaysia Health Campus, 16150 Kota Bharu, Kelantan, Malaysia, \\ tel.: +609-7676409, fax: +609-7676424, e-mail: msakinah@usm.my
}

Abstract Soft tissue sarcoma, especially synovial sarcoma, is extremely rare in infancy, with only a few cases reported worldwide. Due to the particularly small size of the head and neck region in infants, with important anatomical structures in close vicinity to one another, surgical resection is very challenging, if the goal is to ensure total disease elimination as well as maintaining function and good cosmetic outcome postoperatively. In the case reported here, following diagnosis, the child was given three cycles of neoadjuvant chemotherapy followed by infratemporal tumour resection via Bramley-Al-Kayat incision incorporated with a modified Blair incision. Postoperatively, the child recovered well, with no recurrence after three months. This case highlights the important role of a multidisciplinary approach in the diagnosis and managing such rare cases. We also discuss the clinical presentation, imaging features, histopathological features, treatment regime, and prognosis of synovial sarcoma of the infratemporal fossa in children, based on cases reported in the literature.

Keywords: sarcoma, chemotherapy, infratemporal fossa, children

Streszczenie Mięsaki tkanek miękkich, a zwłaszcza mięsak maziówkowy, występują niezwykle rzadko w okresie niemowlęcym. Na całym świecie zgłoszono zaledwie kilka takich przypadków. Ze względu na niewielkie rozmiary obszaru głowy i szyi u niemowląt oraz bliskość ważnych struktur anatomicznych resekcja chirurgiczna jest bardzo trudna, jeśli celem jest całkowite wyeliminowanie choroby oraz zachowanie prawidłowej czynności i dobrych efektów kosmetycznych po zabiegu. W opisywanym przypadku po rozpoznaniu mięsaka maziówkowego u dziecka zastosowano trzy cykle chemioterapii neoadiuwantowej, a następnie przeprowadzono resekcję guza z dostępu podskroniowego przez nacięcie opisane przez Bramleya i Al-Kayata w połączeniu ze zmodyfikowanym nacięciem Blaira. Okres pooperacyjny przebiegł bez powikłań, a po trzech miesiącach nie stwierdzono nawrotu choroby. Opisany przypadek zwraca uwagę na istotną rolę wielodyscyplinarnego podejścia w diagnostyce i leczeniu tak rzadkich nowotworów. Na podstawie przypadków opisanych w piśmiennictwie omówiono również obraz kliniczny, zmiany widoczne w badaniach obrazowych, cechy histopatologiczne, schemat leczenia i rokowanie u dzieci z mięsakiem maziówkowym umiejscowionym w dole podskroniowym.

Słowa kluczowe: mięsak, chemioterapia, dół podskroniowy, dzieci 


\section{INTRODUCTION}

$\mathrm{S}$ oft tissue sarcoma (STS) in children is a rare entity, especially in infants under 1 year of age, where the incidence is only 16 per million population ${ }^{(1)}$. STSs represent $7.3 \%$ of all malignant tumours, with rhabdomyosarcoma being the most common histotype, clocking at $32 \%$, followed by fibrosarcoma ( $24.5 \%)$, and malignant rhabdoid tumour $(14.2 \%)^{(1)}$. Synovial sarcoma (SS), which is one of the histotypes of STS, can be considered as extremely rare ${ }^{(1)}$, and to the best of our knowledge, only three cases of synovial sarcoma in an infant were reported in the literature, two of which developed in the biceps region, while one occurred in the neck. Due to its rarity, cases of SS need to be reported, as its clinical manifestation, diagnosis, and treatment approaches are still not well understood.

\section{CASE REPORT}

A 3-month-old infant presented with a rapidly growing right cheek and buccal swelling associated with squint over the right eye. The symptoms had persisted for over a week. There was no difficulty in feeding or shortness of breath, and the patient was thriving well. There was no history of fever, pain or pus discharge from the mass.

Clinically, the mass was occupying the whole right check, measuring around $5 \times 6 \mathrm{~cm}$, extending superiorly to the right zygoma, inferiorly reaching the angle of the mandible. The mass was firm, non-tender, and fixed to the underlying structure. There were no dilated vessels or skin changes over the mass. Intraoral examination revealed right buccal mass which was pinkish, smooth-surfaced, and firm in consistency. There was no visible breach of mucosa. Otherwise, flexible nasopharyngolaryngoscopic examination showed normal findings in both nasal cavities, and in the nasopharynx, oropharynx and hypopharynx. Bilateral vocal cords were mobile, with a patent airway.

Initial ultrasound scan of the right cheek showed the presence of a hypoechoic mass in the right temporal fos$\mathrm{sa}$, which later proceeded to magnetic resonance imaging (MRI) of the maxillofacial and paranasal sinuses (Fig. 1) showing a soft tissue mass measuring $3.5 \times 2.6 \times 5.4 \mathrm{~cm}$ at its widest dimension, abutting against the lateral wall of the right orbit, and extending superiorly into the right temporal fossa and inferiorly as far as the body of the right mandible. There was no visible destruction of adjacent bones. A biopsy of the mass from the right buccal region was taken, revealing a spindle cell tumour indicative of synovial sarcoma. She was referred to the paediatric oncology department and initially started on a short course of intravenous (IV) dexamethasone $0.5 \mathrm{mg}$ daily for one week, followed by three cycles of neoadjuvant chemotherapy. The regime given followed the European paediatric Soft tissue sarcoma Study Group of non-rhabdomyosarcoma soft tissue sarcoma in childhood (EpSSG NRSTS 2005) protocol which includes premedication with IV mesna $154 \mathrm{mg}$ bolus, followed by IV ifosfamide $3 \mathrm{~g} / \mathrm{m}^{2} /$ day over three hours for three days, and IV doxorubicin $37.5 \mathrm{mg} / \mathrm{m}^{2} /$ day over six hours for two days. At first, chemotherapy was able to regress the progression of mass temporarily, but after the third cycle of chemotherapy, there was no improvement observed. MRI of the maxillofacial region was repeated after the third cycle, showing only minimal regression of the tumour. In view of limited response to chemotherapy, surgical intervention was advocated.

Prior to surgery, the airway was secured by an oroendotracheal tube, followed by the administration of general anaesthesia. The right infratemporal fossa mass was resected via Bramley-Al-Kayat incision incorporated with a modified
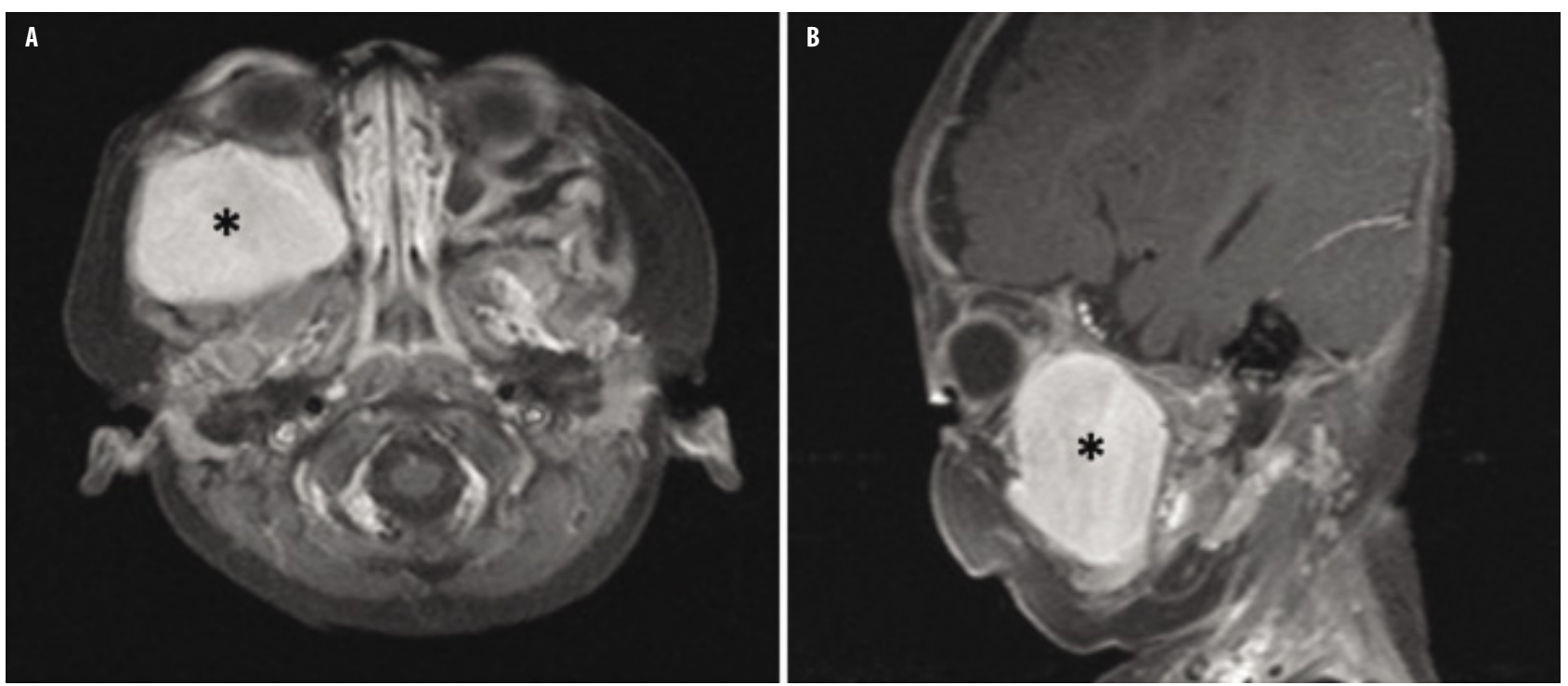

Fig. 1. Axial view of MRI showing a heterogeneous hyperintense mass $\left(^{*}\right)$ in the right infratemporal region, obliterating the fat in the right buccal region (A), and sagittal view of MRI showing the same mass $\left(^{*}\right)$ abutting the floor of the right orbit superiorly and extending inferiorly to the body of the right mandible (B) 

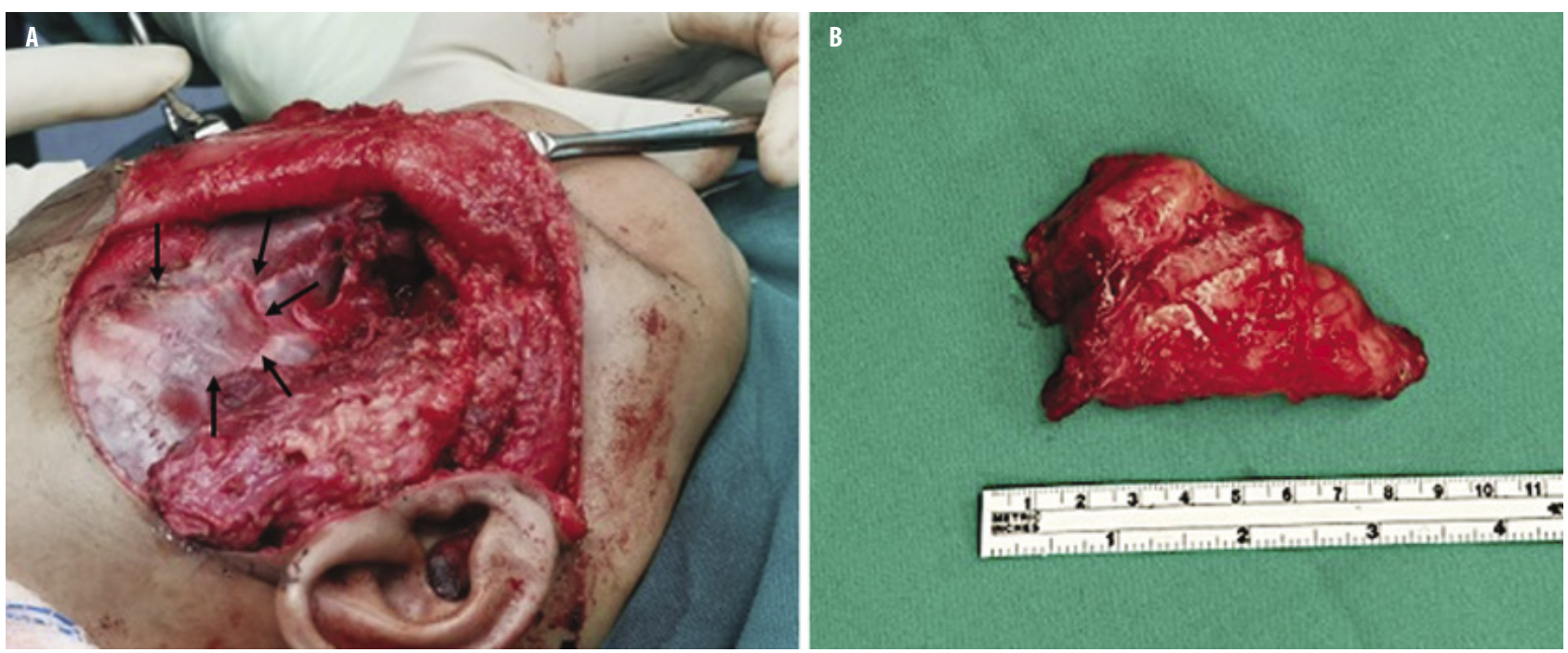

Fig. 2. Intraoperative picture showing the right infratemporal region post tumour removal, with the temporal bone being eggshell thinned (shown by the black arrows) due to the compression effect of the mass (A) and the tumour removed en bloc (B)

Blair incision. The mass was $9 \times 5 \mathrm{~cm}$ in diameter, pinkishwhite in colour, with a smooth surface, firm and well-encapsulated. Intraoperatively, it extended inferiorly to the right angle of the mandible, superiorly encroaching the medial wall of the right orbit, with erosions into the orbital floor, but sparing the orbital content, laterally to the right buccal pad of fat, and posteriorly abutting the right infratemporal fossa. The tumour was successfully removed en bloc. The zygomatic bone was noted to be egg-shell thin, likely from the long-standing compression effect of the mass (Fig. 2). All the branches of the right facial nerve were identified anatomically and physiologically, however the temporofacial branch of the main trunk was sacrificed for surgical access. Postoperatively, she was discharged after completing oneweek course of IV amoxicillin and clavulanic acid $20 \mathrm{mg} / \mathrm{kg}$. During subsequent follow-up, the surgical wound was wellhealed, and there was no recurring mass at the operative site. MRI of the maxillofacial regional at three months postsurgery showed no residual disease. The child is well, with no feeding difficulties, and thriving.

\section{DISCUSSION}

STSs are a heterogeneous group of tumours arising from mesenchymal cells. One of the variants is SS which, despite its name, does not arise from the synovial membrane. Classically, it usually occurs in the extremities, especially near large joints, but it can occur anywhere in the body distant from joint spaces and not limited to periarticular sites ${ }^{(2)}$. The most common presenting symptom in SS is progressive painless mass ${ }^{(3)}$. Other differentials that can be considered in mass developing in the infratemporal fossa are rhabdomyosarcoma, adenoid cystic carcinoma, and schwannoma. Fortunately, in our patient, the mass neither obstructed the airway, nor impaired her feeding pattern, al-
In view of the rarity of SS in the head and neck region, especially in an infant, information regarding appropriate therapy is limited. The management of sarcoma in the head and neck region differs from sarcoma developing in the limbs. The mainstay of treatment in head and neck sarcoma is complete surgical resection with a cuff of surrounding tissue beyond the identifiable margin of the tumour. For tumours in locations other than the head and neck, a $5 \mathrm{~cm}$ margin is recommended, but this is not possible in the head and neck area due to close proximity of vital structures in these regions and furthermore, not possible in small children where the anatomy itself is already minuscule. In our case, we had to sacrifice the temporofacial branch of the facial nerve to gain access to the tumour. We also failed to get a $5 \mathrm{~cm}$ clearance from the tumour margin due to the size of the patient's facial structures. Because of a possible compromised margin, adjuvant radiotherapy is recommended, but it does not supersede total local resection of the tumour ${ }^{(3)}$. Thus, treatment of head and neck SS should be based on a multimodal approach consisting of tumour resection with adjuvant radiotherapy and chemotherapy for paediatric sarcoma $^{(3)}$. It is of utmost importance to get input from a multidisciplinary team meeting involving a paediatric oncologist, maxillofacial surgeon, ophthalmologist and speech therapist to ensure that the patient receives the best treatment options, with locoregional control of the disease, and reduce morbidity on the function of vital structures in the head and neck area.

Radiotherapy for paediatric sarcoma is not standardised. The dosage varies depending on histologic subtypes, extent of the tumour and its response to the chemotherapeutic agent. Non-rhabdomyosarcoma soft tissue sarcoma often needs $60 \mathrm{~Gy}$ in 30 fractions. Some long-term side effects of radiotherapy use in paediatric patients have been documented, such as cataracts, endocrine deficiencies, delayed facial bone growth causing facial asymmetry, neurocognitive 


\begin{tabular}{|c|c|c|c|}
\hline Cases & $\mathbf{1}$ & $\mathbf{2}$ & $\mathbf{3}$ \\
\hline Age & 11 months old & 3 days old (premature at 32 weeks) & 3 days old \\
\hline Gender & Female & Male & Female \\
\hline Clinical presentation & $\begin{array}{c}2-3 \text { weeks of left } \\
\text { submandibular swelling }\end{array}$ & $\begin{array}{c}\text { Left upper arm (humerus and scapula) swelling } \\
\text { with multiorgan metastases (bilateral suprarenal } \\
\text { glands, right liver lobe, right kidney and brain) } \\
\text { at diagnosis }\end{array}$ & $\begin{array}{c}\text { Left upper arm (biceps) swelling following BCG } \\
\text { (bacillus Calmette-Guérin) injection, } \\
\text { with no evidence of metastases }\end{array}$ \\
\hline Size of tumour & $6 \mathrm{~cm}$ diameter & $10 \times 9 \times 8 \mathrm{~cm}$ (MRI) & $3.4 \times 3.1 \times 2.4 \mathrm{~cm}$ (MRI) \\
\hline Margin status & - & - & Free margin \\
\hline Treatment & - & $\begin{array}{c}\text { Planned for chemotherapy but the child passed } \\
\text { away on day } 10 \text { due to respiratory distress }\end{array}$ & $\begin{array}{c}\text { Three cycles of chemotherapy followed by surgical resection } \\
\text { of tumour and another three cycles of chemotherapy after } \\
\text { resection. The child received six cycles of ifosfamide } \\
900 \mathrm{mg} / \mathrm{m}^{2} / \text { day for three days and adriamycin } \\
15 \mathrm{mg} / \mathrm{m}^{2} / \mathrm{day} \text { for two days given once every three weeks }\end{array}$ \\
\hline Outcome & - & Köse et al. (2014) & $\begin{array}{c}\text { Well at } 12 \text { months' follow-up, with normal growth } \\
\text { and development }\end{array}$ \\
\hline Author(s) (year) & Kester (1990) & Radhakrishnan et al. (2016) \\
\hline
\end{tabular}

Tab. 1. Summary of cases of synovial sarcoma found in children less than two years old

defects, and impaired dentition. To overcome this, other options are being developed such as intensity-modulated radiation therapy (IMRT) and proton beam therapy (PBT). The use of proton beams has shown promising result in reducing the early complications of radiotherapy like mucositis, but long-term complications are still controversial ${ }^{(4)}$.

The role of chemotherapy is well established in certain subtypes of sarcoma including rhabdomyosarcoma, osteosarcoma, and Ewing sarcoma. For other sarcoma subtypes, the role of chemotherapy is not well understood. In our patient, we followed the European paediatric Soft tissue sarcoma Study Group 2005 protocol, which advocates the use of ifosfamide and doxorubicin ${ }^{(5)}$. Some authors, however, are sceptical on the use of chemotherapy, as in some case series it has failed to show a significant improvement in survival, and only advocate chemotherapy for high-risk features such as high-grade tumour or the presence of distant metastases $^{(2)}$. Most treatment failures are caused by local recurrence. They are associated with the biphasic subtype, large size on presentation, skull base location, positive margin, bone invasion, and lack of adjuvant therapy. The highest overall and disease-specific survival rates are noted in patients that underwent surgery, followed by postoperative radiotherapy ${ }^{(6)}$. Colville et al. showed promising results with multimodality treatment in paediatric cases, with an overall survival rate of $83 \%{ }^{(3)}$. Tab. 1 shows a summary of cases of SS found in children less than two years old ${ }^{(7-9)}$.

\section{CONCLUSIONS}

In conclusion, SS tumours are extremely rare. Their occurrence in the infratemporal fossa region and in children is even rarer and more challenging to manage. However, clinicians should be aware of this clinical entity which may develop in the head and neck region, as early diagnosis and prompt treatment are crucial. This case shows the importance of a multidisciplinary team approach. The debulking of the tumour was found to be an effective way to reduce the chemotherapy burden and improve the patient's outcome.

\section{Conflict of interest}

The authors have no financial or personal connections to declare with other persons or organisations that could adversely affect the content of the publication and claim the right to this publication.

\section{References}

1. Sultan I, Casanova M, Al-Jumaily U et al.: Soft tissue sarcomas in the first year of life. Eur J Cancer 2010; 46: 2449-2456.

2. McCarville MB, Spunt SL, Skapek SX et al.: Synovial sarcoma in pediatric patients. AJR Am J Roentgenol 2002; 179: 797-801.

3. Colville RJ, Charlton F, Kelly CG et al.: Multidisciplinary management of head and neck sarcomas. Head Neck 2005; 27: 814-824.

4. Huh WW, Fitzgerald N, Mahajan A et al.: Pediatric sarcomas and related tumors of the head and neck. Cancer Treat Rev 2011; 37: 431-439.

5. Ferrari A, De Salvo GL, Brennan B et al.: Synovial sarcoma in children and adolescents: the European pediatric soft tissue sarcoma study group prospective trial (EpSSG NRSTS 2005). Ann Oncol 2015; 26: 567-572.

6. Lee N, Shin E: Treatment outcomes for patients with synovial sarcoma of the head and neck. Expert Rev Anticancer Ther 2008; 8: 371-373.

7. Kester NL: Synovial sarcoma in the neck of an eleven month old girl. Pediatr Radiol 1990; 20: 487.

8. Köse D, Annagür A, Erol C et al.: Synovial sarcoma in a premature newborn. Pediatr Int 2014; 56: e17-e20.

9. Radhakrishnan V, Joel A, Sundersingh $S$ et al.: Synovial sarcoma in a neonate. Indian Pediatr 2016; 53: 345-346. 